\title{
STEREOTIP KEHIDUPAN WARIA DALAM NOVEL RUMAH ILALANG KARYA STEBBY JULIONATAN
}

\author{
Agus Syaiputra Sugiarto, Eggy Fajar Andalas \\ Prodi Pendidikan Bahasa Indonesia, Universitas Muhammadiyah Malang \\ Jalan Raya Tlogomas 246, Malang, Indonesia \\ agussyaiputra533@gmail.com
}

\begin{abstract}
ABSTRAK: Penelitian ini bertujuan mengetahui Stereotip yang melekat pada kehidupan waria dalam novel Rumah Ilalang karya Stebby Julionatan. Stereotip yang dimaksud adalah gambaran atau cerminan kehidupan waria yang terjadi pada lingkungan masyarakat dalam karya sastra. Jenis penelitian ini adalah penelitian deskriptif-kualitatif dengan pendekatan Sosiologi Sastra. Sumber penelitian ini berasal dari novel Rumah Ilalang karya Stebby Julionatan. Data penelitian ini berupa kutipan, kalimat, dan paragraf yang berupa gambaran atau cerminan kehidupan waria. Teknik pengumpulan data dilakukan dengan metode membaca Novel dan mengidentifikasikan konteks permasalahan yang akan diteliti. Teknik analisis data menggunakan model Miles dan Humberman melalui langkah-langkah (1) penyeleksian data, (2) pemaparan data, dan (3) penarikan kesimpulan. Hasil memperlihatkan waria direpresentasikan dalam tiga aspek, yaitu (1) tidak beragama, (2) tidak memiliki pekerjaan yang tetap, (3) tidak diterima dengan baik oleh masyarakat.
\end{abstract}

KATA KUNCI: novel rumah ilalang; stereotip; waria

\section{STEREOTYPES OF TRANSVESTITE LIFE IN RUMAH ILALANG BY STEBBY JULIONATAN}

ABSTRACT: This study aims to determine the stereotypes inherent in transvestite life in the Rumah Ilalang by Stebby Julionatan. This stereotype is a picture or reflection of transvestite life that occurs in the community environment in literary works in the form of novels. This type of research is descriptivequalitative research with a sociological approach to literature. The source of this research is Rumah Ilalang by Stebby Julionatan. This research datas are the form of quotes, sentences, and paragraphs in the form of a picture or reflection of the life of transvestites. Data collection techniques are done by reading novels and identifying the context of the problem to be studied. The data analysis technique used in this study is the data analysis design presented by Miles and Humberman through the steps (1) selecting data, (2) disclosing data, and (3) drawing conclusions. The result show transgenders were represented in three aspects, namely (1) not having religion, (2) not having a permanent job, (3) not being well received by the community.

KEYWORDS: rumah ilalang novels; stereotypes; transvestite

\begin{tabular}{lccc}
\hline Diterima: & Direvisi: & Disetujui: & Dipublikasi: \\
2020-04-24 & 2020-11-01 & $2020-11-15$ & $2021-03-28$ \\
& & & \\
Pustaka & Sugiarto, A., \& Andalas, E. (2021). STEREOTIP KEHIDUPAN WARIA DALAM NOVEL \\
& RUMAH ILALANG KARYA STEBBY JULIONATAN. Fon : Jurnal Pendidikan Bahasa dan \\
& Sastra Indonesia, 17(1), 1-13. doi:https://doi.org/10.25134/fjpbsi.v17i1.2756 \\
\hline
\end{tabular}

\section{PENDAHULUAN}

Novel merupakan gambaran dari realitas (Iman \& Andalas, 2019; Nurgiyantoro, 2010). Hal ini karena pada dasarnya realitas kehidupan manusia merupakan bahan baku dalam penciptaan karya sastra (Andalas, 2017; Sugiarti \& Andalas, 2018). Karenanya tidak jarang ditemui kesejajaran peristiwa yang ada di dalam karya sastra dan di dalam kehidupan nyata.

Stereotip merupakan salah satu unsur dalam kehidupan manusia yang sering digunakan sebagai dasar pengembangan cerita dalam karya sastra. Samovar (2001:315) menyatakan stereotip sebagai penilaian atas sekelompok orang yang dianut oleh budaya tertentu. Dengan kata lain, stereotip merupakan hasil dari 
konstruksi sosial-budaya yang dihasilkan oleh masyarakat tertentu (Artawan, 2015). Stereotip juga sering diartikan orangorang yang berprasangka sebelum orang tersebut mempunyai kesempatan untuk berinteraksi. Stereotip sering juga diartikan penelitian terhadap seseorang hanya berdasarkan pandangan kelompok dimana orang tersebut dapat dikategorikan.

Novel Rumah Ilalang karya Stebby Julionatan merupakan salah satu karya sastra yang berbicara mengenai stereotip yang berkembang dalam masyarakat terhadap waria. Novel ini menarik karena hampir semua tokohnya adalah waria dengan latar belakang yang beragam. Novel ini berkisah mengenai tokoh utama, seorang waria, bernama Tabita. Ia mempunyai nama asli bernama Alang. Ia menjadi seorang waria karena keinginan orang tuanya untuk memiliki seorang anak perempuan. Karena keinginan inilah membuat Alang terpuruk dan menjadi seorang waria untuk membahagiakan kedua orang tuanya. Akan tetapi, setelah mengetahui Alang menjadi waria, kedua orang tuanya justru mengusirnya dari rumah. Alang akhirnya memutuskan untuk meninggalkan rumah dan berkelana ke berbagai tempat.

Seiring dengan kepergiannya, Alang mengubah namanya menjadi Tabita. Dalam pengembaraannya, ia bertemua dengan seorang waria lain bernama Mami Nancy. Mami Nancy merupakan seorang waria yang memiliki butik yang sangat besar. Tabita diangkat oleh Mami Nancy menjadi salah satu karyawannya. Di sinilah awal dari perubahan kehidupan dalam diri Tabita. Berbagai gambaran mengenai sosok waria yang hidup di masyarakat seolah berbeda dengan realitas kehidupan yang dijalani oleh tokoh-tokoh waria di dalam cerita.

Gambaran kehidupan Tabita dengan tokoh-tokoh waria lain dalam novel ini merupakan representasi dari kehidupan waria yang ada di sekitar kita. Waria memiliki stereotip yang buruk di dalam masyarakat, sehingga banya terjadi perlakukan yang tidak adil kepada mereka.

Sebagai sebuah novel yang menganggkat realitas kehidupan manusia, Novel Rumah Ilalang menghadirkan dimensi kehidupan yang jarang untuk diperbincangkan, yaitu dunia waria. Karenanya, novel ini menarik untuk diteliti utamanya dari aspek stereotip yang hidup dalam masyarakat dalam memandang orang-orang seperti Tabita. Penelitian ini bertujuan mendeskripsikan stereotip yang kehidupan waria yang tergambarkan dalam novel Rumah Ilalang karya Stebby Julionatan.

Novel Rumah Ilalang karya Stebby Julionatan tersebut tergolong novel baru dan belum pernah diteliti sebelumnya. Meskipun begitu berdasarkan penelitian sebelumnya mengenai stereotip yang ada dalam berbagai produk budaya menunjukkan bahwa stereotip merupakan hasil konstruksi masyarakat yang melembaga antargenerasi sehingga sulit untuk diubah (Andalas \& Prihatini, 2018; Artawan, 2015; Fibiani \& Andalas, 2020; Paynter, 2011). Dibutuhkan kerangka kesadaran kritis yang mampu membongkar dimensi kritis masyarakat sehingga adanya perubahan terhadap hal ini (Arivia, 2002; Earles, 2016). Karenanya, penelitian ini penting dilakukan untuk mengisi dimensi tersebut. Dengan penelitian ini akan diperoleh gambaran mengenai stereotip yang ada dalam masyarakat terhadap kehidupan waria.

Untuk membantu menjawab masalah penelitian digunakan teori sosiologi sastra. Sosiologi sastra merupakan pemahaman dan totalitas terhadap karya sastra dengan memperhatikan hubungannya dengan masyarakat (Kartikasari dkk., 2014). Hal ini karena terdapat pengaruh dari latar 
belakang masyarakat tempat berbagai bahan baku karya sastra tersebut ditulis (Damono, 1978). Pengaruh realitas yang ada dalam masyarakat dalam pengonstruksian dalam karya sastra yang dimaksud adalah mengenai stereotip terhadap kelompok tertentu yang hidup di masyarakat. Dalam konteks ini adalah kelompok waria.

Stereotip dalam penelitian ini diartikan sebagai kepercayaan tentang sifat atau ciri-ciri kelompok sosial tertentu yang hidup dalam masyarakat (Baron, Branscombe, \& Byrne, 2008:188; Franzoi, 2008:199). Lebih jauh, Stangor (2011) menjelaskan stereotip jika berada dalam ranah kognitif sedangkan prasangka dalam ranah afektif dan diskriminasi berada dalam ranah prilaku yang muncul.

\section{METODE}

Penelitian ini merupakan jenis kualitatif dengan metode diskriptif. Pendekatan yang digunakan adalah sosiologi sastra. Sumber data penelitian ini adalah Novel Rumah Ilalang karya Stebby Julionatan yang diterbitkan oleh Basabasi pada 2019. Data penelitian ini narasi, dialog, dan pemikiran tokoh yang memperlihatkan mengenai stereotip terhadap waria. Data-data dikumpulkan dengan beberapa langkah yaitu: pertama, membaca novel keseluruhan, kedua, mengidentifikasi permasalahan yang menjadi sebagai konteks novel. Ketiga, membuat catatan setiap data yang berhubungan dengan permasalahan penelitian. Data-data yang telah dikumpulkan kemudian dianalisis menggunakan model Miles dan Huberman, yaitu reduksi, penyajian data, interpertasi, dan penarikan simpulan (Sugiarti, Andalas, \& Setiawan, 2020).

\section{HASIL DAN PEMBAHASAN}

Pada pembahasan ini dijelaskan bahwa stereotip yang timbul dalam masyarakat terhadap waria dan kesenjangan ekonomi yang terjadi pada waria. Berdasarkan analisis ditemukan stereotip dalam tiga wujud realitas kehidupan waria dalam Novel Rumah ilalang karya Stebby Julionatan, yaitu 1) tidak beragama, 2) tidak mempunyai pekerjaan yang tetap, dan 3) tidak diterima dengan baik oleh masyarakat. Stereotip waria yang timbul pada masyarakat dijelaskan sebagai berikut.

\section{Tidak Beragama}

Dalam novel Rumah Ilalang, pengarang menggambarkan bagaimana waria tidak mempunyai kepercayaan yang menjadi pedoman hidup seseorang. Hal ini sangat terlihat di dalam novel sehingga permasalahan tersebut menjadi topik utama permasalahan yang berada pada novel. Stereotip jika waria merupakan manusia yang tidak beragama dalam novel tergambarkan sebagai berikut.

Ya, dia muslim, dia tidak
terdaftar sebagai anggota
jemaat dan dia juga tidak
dibaptis dan kami
muslim...Jumlah kami banyak,
kami mayoritas di kota dan
negara ini. Maka, sedikit saja
golongan kami membuat
masalah, tak segan-seganlah
kami mengadili kalian dengan
unsur penghinaan agama.
Imbasnya, mungkin akan lebih
dari itu, gereja kalian kami
luruk secara masal, main
orasi dan silat lidah didepan,
seorang oknum pengacau
dilibatkan untuk memicu
tawuran... dan, dibakar
(Julionatan, 2019, hlm. 109).

Kutipan tersebut memperlihatkan pandangan dan perlakukan masyarakat terhadap sosok waria. Masyarakat bingung terhadap identitas keagamaan Tabita karena ia beridentitas Muslim 
tetapi sering pergi ke geraja. Akan tetapi, ia juga tidak beragama nasrani karena belum pernah dibaptis. Menurut Gea (2006) agama adalah proses hubungan manusia yang dirasakan terhadap sesuatu yang diyakininya, bahwa sesuatu lebih tinggi daripada manusia. Jadi agama adalah sesuatu keyakinan yang sangat diyakini dalam diri seseorang untuk menuju tujuan yang lebih baik. Dengan demikian waria tersebut tidak memiliki keyakinan dalam dirinya yang menjadikan waria tersebut bingung terhadap tujuan akhir hidupnya yang memilih untuk menjalani hidup yang tidak bergama. Dalam cerita waria tersebut bisa dibilang menyelewengkan agama. Agama yang semula semula sudah menjadi identitas yang bertanda dari lahir menjadi penyelewengan dengan seringnya waria tersebut berkunjung ke gereja setiap minggu dan ikut beribadah. Kondisi pergaulan atau melewati masa remaja, kondisi psikologis remaja ternyata mempunyai pengaruh yang cukup signifikan dalam agama yang dipercayai. Perkembangan kognitif yang sudah mencapai taraf formal dan operasional. Dalam konteks permasalahan dalam novel Tabita adalah seorang remaja yang baru menduduki bangku SMA, dari segi pergaulan siswa SMA memilki kondisi yang sangat sensitif terhadap hal yang baru dan ingin mengetahuinya. Hal yang terjadi dalam permasalahan dalam novel, di mana Tabita tersebut mempunyai salah pergaulan yang mengakibatkan Tabita kesulitan menentukan identitas dirinya dan hanya mengikuti pengaruh dari lingkungan barunya.

Kondisi ini dapat terjelaskan berdasarkan penelitian Wulff (1991). Berdasarkan penelitiannya sangat jarang adanya remaja yang dengan intens terlibat dalam pemantapan kehidupan beragama. Namun yang diteliti Wulff dalam bukunya yaitu dalam masa remaja dan masa kanakkanak cenderung mempunyai kesamaan, terutama ciri egosentris dan perilaku keagamaan yang ritualistik dan superfisial. Jadi dalam permasalahan dalam novel, masa remaja dan masa kanak-kanak cenderung mempunyai kesamaan. Perilaku yang terjadi sekarang yang dilakukan Tabita juga memiliki kesamaan yang dilakukan dengan masa kanak-kanak. Sedikit diceritakan dalam novel bahwa kedua orang tua Tabita sejak Ibunya hamil sangat ingin mempunyai anak perempuan yang diharapkan dan ketika lahir kedua orang tuanya memperlakukannya seperti anak perempuan. Akibat perlakukan ini mengakibatkan gangguan psikologis pad adiri Tabita yang mengakibatkannya mempunyai perilaku seperti wanita. Tabita menjadi waria atas kehendak orang tuanya yang menginginkan mempunyai anak perempuan.

Permasalahannya sendiri
pelik. Ia..., maaf, muslim.
Tidak terdaftar sebagai
anggota jemaat gereja. Sulit
bagi saya nanti untuk
menjawab atau
mempertanggungjawabkan
keputusan yang saya ambil.
Mendengar jawaban itu, jauh
didalam hatinya, tania dan
ahmad sebenarnya sudah
paham. (Julionatan, 2019, hlm
102)

Dalam kutipan novel di atas yaitu jawaban yang dilontarkan terhadap pendeta yang didatangi oleh kerabat Tabita yang bernama Ahmad dan Tania. Perlu diperhatikan bahwa Ahmad dan Tania adalah kerabat Tabita yang sudah lama menemani Tabita sampai ia meninggal. Persahabatannya dimulai sejak Tabita bertemu dengan mami Nancy yang juga berstatus sebagai waria dan memiliki usaha yang sangat sukses. Tabita ketika bertemu mami Nancy merasa sangat 
nyaman dengan perlakuan mami Nancy. Mereka bertemu di rumah mami Nancy dan mami Nancy membuatkan segelas teh dan mengajak Tabita berbincang-bincang menceritakan bagaimana ceritanya Tabita bisa sampai ke rumah mami Nancy dan Tabita mengajukan pekerjaan untuk ikut membantu dibutik mami Nancy yang lumayan besar. Tanpa basa-basi mami Nancy langsung menerima tawaran Tabita itu tanpa persyaratan. Dengan hati yang senang dan gembira Tabita menatap tatapan mami Nancy. Dalam masa hidupnya Tabita memang tidak bisa diketahui identitasnya, Tabita menjadi orang tidak gampang terbuka terhadap orang sembarangan. Tabita sering menyembunyikan identitasnya jika ada yang bertanya.

Untuk masalah keyakinan atau agama Tabita juga tidak jelas identitasnya. Semenjak Tabita bekerja di tempat mami Nancy Tabita sering berangkat ke gereja pada hari minggu untuk mengikuti sembahyang di gereja. Tabita juga sangat rajin setiap hari minggu selalu mengikuti ibadah di gereja. Pada akhirnya Tabita meninggal akibat kecelakaan karena kurang berhati-hati mengendarai motor di jalan akhirnya Tabita ditabrak oleh truk besar bermuatan banyak mengakibatkan tubuh Tabita tertindas oleh roda besar truk tersebut. Kejadian tersebut mengundang tangis haru keluarga mami Nancy dan sahabat karib Tabita yaitu Tania dan Ahmad.

Perlu diketahui Tania juga waria. Mendengar kabar dari rumah sakit yang menangani jenazah Tabita mami Nancy bergagas segera berangkat ke rumah sakit yang sudah diketahui alamatnya oleh dokter yang menelpon mami Nancy. Mami Nancy bergagas berangkat dengan ke dua sahabat Tabita tersebut. Disepanjang perjalanan di dalam mobil mami Nancy menangis dengan sikap tidak percaya bahwa yang meninggal adalah Tabita. Setelah tiba di rumah sakit mami
Nancy menemui suster dan menuju ke kamar jenazah. Di dalam kamar jenazah mami Nancy ingin memastikan bahwa yang meninggal itu benar-benar Tabita dan ingin membuka jenazah yang sudah terbujur kaku, tapi suster melarang mami Nancy membukanya dikarenakan tubuh Tabita sudah tidak lengkap lagi. Dengan kondisi seperti itu mami Nancy menyuruh kedua sahabat Tabita untuk menyiapkan prosesi pemakaman. Dalam mencari tempat pemakaman umum di sekitar rumah mami Nancy, Tania dan Ahmad meminta izin kepada ketua RT setempat. Namun tanggapan ketua RT tersebut tidak sesuai rencana Tania. Ketua RT tersebut mempermasalahkan identitas Tabita yang jarang ke masjid namun setiap hari minggu mengikuti ibadah di gereja. Kemudian kedua sahabat tersebut berpikir panjang bagaimana Tabita dimakamkan dengan cara kristen saja, dan Ahmad setuju kemudian Ahmad bergagas mencari pendeta yang dekat dengan rumah mami Nancy yang gerejanya sering didatangi oleh Tabita. Namun tidak sesuai dengan rencana juga, pendeta yang dimintai tolong untuk mengurus Tabita menolak permintaan Ahmad karena Tabita tidak terdaftar sebagai jamaat gereja walaupun setiap minggu rajin ke gereja. Kondisi ini memperlihatkan pengaruh lingkungan yang kuat dalam membentuk identitas seseorang. (Clark, 1958) menyebut ciri kehidupan beragama anak-anak bersifat autoritatif, karena keberagamaan anakanak masih didominasi oleh keberagaman orang dewasa di sekitarnya, terutama orang tuanya. Dalam pernyataan di atas menurut Clark yaitu ada suatu keterkaitan dengan orang sekitarnya terutama orang tua menjadi suatu pandangan yang sangat menonjol bagi perkembangan anak diusia anak-anak sampai dewasa.

Pengaruh yang dialami oleh Tabita yaitu sebuah tuntutan di mana kedua orang tuanya ingin memiliki seorang anak perempuan yang ingin dibanggakan 
karena orang tua Tabita tidak memiliki keturunan perempuan karena kakak yang pertama Tabita perempuan tapi umurnya tidak lama dalam kandungan. Tuntutan kedua orang tua Tabita akan menjadi sebuah bayang-bayang yang berat untuk seorang anak masih memiliki usia dibawah umur dengan tingkat kelabilan berpikir masih membayangi pemikiran seorang anak diusia remaja. Jadi Tabita memutuskan menjadi waria tidak dikarenakan keinginan sendiri dengan sebuah motivasi menginginkan Tabita menjadi waria karena pengaruh kehidupan keluarga yang menjadikan Tabita menjadi waria dengan kedua orang tuanya menginginkan mempunyai anak perempuan. Dengan keinginan kedua orang tuanya Tabita memiliki anak perempuan Tabita merasa tertekan dan mempengaruhi kehidupannya dan paling bahaya adalah mempengaruhi psikis yang mengakibatkan depresi sehingga Tabita berkeinginan menjadi waria. Awalnya kedua orang tuanya melarang tapi dengan keinginan Tabita sudah bulat dan memilih untuk melarikan diri dari rumah. Dengan sikap seperti itu kedua orang tuanya merasa khawatir dan melarangnya sehingga Tabita diusir dari rumah dan tidak akan mengakui Tabita sebagai anak oleh kedua orang tuanya.

Allport (1950) mengajukan enam kriteria sebagai indikasi kehidupan beragama yang matang, yaitu: terdiferensiasi dengan baik, dinamis, konsisten, kompherensif, integral, dan heuristik. Yang dimaksud kehidupan beragama (1) diferensiasi dengan baik yaitu menerima agama yang dianutnya secara kritis maksudnya adalah bahwa menerima agama dengan kekanakkanakan, yaitu dengan menerima agama yang dianutnya secara apa adanya dan tidak bisa merasionalkan pada pemikiran yang kritis. (2) dinamis adalah apabila agama mampu mengontrol dan mampu mengarahkan motif-motif pada aktivitas individu. Agama bukan merupakan aktivitas keagamaan individu itu sendiri, melainkan dilaksanakan dengan kepentingan umat dan agama itu sendiri. Disini sifat egois sudah tidak ada lagi dan agama bisa merubah perilaku sesorang dengan kepercayaan. (3) konsisten adalah adalah keselaran tingkah laku sesorang dengan nilai-nilai yang terkandung dalam agamanya. Di sini moralitas dengan agama menjadi menyatu dalam seluruh aspek kehidupan beragama dan agama telah memberikan arah langkah bagi yang bisa konsisten. (4) komprehensif adalah bahwa agama yang dianut kepada seseorang akan menjadi batasan terhadap dirinya dan sesuatu yang dilakukan oleh seseorang akan kembali keada dirinya. Disini seseorang akan menjadi bisa menerima perbedaan dalam beragama dan bisa menerima berbagai keyakinan yang dipercayai masyarakat. (5) integral di sini yaitu seseorang telah menjadikan itegral sebagai bagian dari kehidupan, yaitu menyatukan agama dengan kehidupan iilmu pengetahuan alam (sains). Bukan agama menjadi pro dan kontra ilmu pengetahuan alam melainkan keduanya sudah tidak bisa dipisahkan karena sudah menjadi satu kesatuan. (6) heuristik adalah seseorang menyadari bahwa adanya keterbatasan terhadap kehidupan beragama dan seseorang akan berusaha meningkatkan pengetahuan dan penghayatan agama yang dianutnya. Jadi, berikut adalah ulasan mengenai kepercayaan beragama sehingga Tabita memiliki kekurangan dalam memilih kepercayaan yang ingin dianutnya dan bukan semata-mata Tabita menjadi seorang waria.

\section{Tidak Memiliki Pekerjaan Tetap}

Pekerjaan tidak bisa dipisahkan oleh kehidupan manusia karena untuk berlangsungnya hidup. Pekerjaan yang dimiliki waria tersebut tidak mempunyai ketetapan dan memiliki pekerjaan yang 
dilarang agama dan pemerintah. Stereotip tidak memiliki pekerjaan yang tetap tergambarkan sebagai berikut.

Saya ingin bekerja dibutik ini, boleh kah?. Kau memandangnya terkejut. Terkejut pada pertanyaan yang begitu gegas dan prematur itu. Tapi, dalam keterkejutanmu, yang tampak pada dirinya adalah keraguan. Hingga dia berujar, "saya lulusan komunikasi, tapi saya tidak sempat membawa ijazah. Saya diusir dari rumah," ujar Tabita. Namun sebenarnya membohongi Nancy soal alasannya tak membawa serta lembaran-lembaran kertas ijazah itu bersamanya.(Julionatan, 2019, hlm. 14)

Dengan penampilan yang seperti waria sangatlah berpengaruh bagi pencarian pekerjaan yang selayaknya manusia uumnya. Karena waria dalam pekerjaan dianggap tidak akan bisa mengatasi semua masalah pekerjaan terutama suatu pekerjaan yang membutuhkan tenaga ekstra. Dari segi ini masyarakat menyimpulkan bahwa waria tidak bisa mengatasi semua masalah pekerjaan sehingga berdampak pada berlangsungnya kehidupan waria untuk mencari pekerjaan yang tetap dan pekerjaan yang sama seperti manusia umumnya. Meskipun tentunya pandangan ini tidak dapat dibenarkan sepenuhnya.

Sama, Itulah pengalamanmu berpuluh-puluh tahun yang lalu ketika kau terdampar ditempat ini. Saya ingin bekerja dihomeless ini, boleh kah?. "Mmmm... baiklah, maukah kau duduk dulu, Tabita? Aku akan membuatkanmu minum. Kau mau apa, kopi atau teh. (Julionatan, 2019, hlm. 16)

Untuk mencari pekerjaan Tabita sangatlah susah, karena kesusahan ingin mendapatkan pekerjaan yang tetap Tabita harus berganti tempat pekerjaannya. Dalam cerita pada kutipan novel tersebut, Tabita bertemu dengan mami Nancy yang sedang bertemu dijalan. Mami Nancy sedang perjalanan ke pasar. Mami Nancy setelah itu melihat seorang Tabita yang kebingungan mencari angkutan umum. Mami Nancy langsung membawa Tabita ke dalam mobil hingga Tabita dibawa ke rumah mami Nancy.

Dalam perjalanan pulang Tabita dan mami Nancy sedang berkenalan dan bercakap-capak dengan baik. Tabita dan mami Nancy merasakan kecocokan keduanya. Setelah sampai rumah mami Nancy dan Tabita kembali melanjutkan percekapan yang sangat asik ditengah perjalanannya tersebut. Setelah berbincang-bincang panjang dan lebar Tabita berpikiran untuk menanyakan pekerjaan dibutik mami Nancy, karena Tabita melihat sebuah butik yang besar yang berada didekat garasi mobil. Tabita menanyakan pekerjaan dengan mami Nancy dan ternyata mami Nancy tidak keberatan sama sekali dan Tabita tidak sama sekali diberikan persyaratan dan tidak disusahkan karena mami Nancy sudah percaya sekali kepada Tabita karena telihat dengan bicara Tabita dan perilaku yang sangat sopan ketika pertama kali Tabita bertemu mami Nancy.

Ketika sudah selesasi pekerjan Tabita langsung dijelaskan prosedurprosedur dalam bekerja dibutik mami Nancy. Tabita sangat mendengarkan dengan teliti apa yang diterangkan mami Nancy. Tabita sangat senang sekali mendapatkan pekerjaan dan dia merasa 
pekerjaan ini pekerjaan yang bisa menetap dan Tabita merasa senang sekali karena dia tidak lagi mencari pekerjaan lagi untuk melanjutkan kehidupan dengan keadaan fisiknya yang seperti waria tersebut.

Menurut (As'ad, 2002, hlm. 46) pada hakikatnya orang bekerja tidak saja untuk mempertahankan kelangsungan hidupnya, tetapi juga bertujuan untuk mencapai taraf yang lebih baik. Dalam pernyataan As'ad adalah seseorang yang ingin bekerja bukan merupakan keinginan untuk melangsungkan kehidupan selanjutnya, melainkan seseorang yang ingin bekerja adalah seseorang yang ingin mencapai taraf yang lebih baik. Hal yang dimaksud taraf yang lebih baik dalam pekerjaan adalah seseorang tersebut ingin mengembangkan pengertahuan dan kemampuan dalam pekerjaan yang ingin dilakukan.

Pekerjaan buka samata-mata mencari uang atau mengurangi pengangguran, pekerjaan merupakan gambaran seseorang dalam hidup bermasyarakat, dalam masyarakat pekerjaan dianggap sangat penting bagi seseorang. Masyarakat menilai seseorang dengan pekerjaannya. Oleh karena itu, seseorang yang ingin bekerja merupakan sebuah keinginan untuk menjadikan dirinya lebih baik dari segi taraf kehidupan bermasyarakat. Pernyataan ini mempunyai keterlibatak terhadap permasalahan novel tersebut, yaitu Tabita yang dulu mempunyai pekerjaan yang tidak tetap dan sering Tabita mencari pekerjaan kesusahan dengan kondisinya yang seperti waria. Tabita mencari pekerjaan untuk melangsungkan kehidupannya, selain itu Tabita juga memikirkan taraf kehidupannya yang baik lagi dengan bekerja. Dengan kondisi Tabita seperti waria, Tabita ingin memperlihatkan dirinya bahwa waria yang seperti dia juga bisa bekerja seperti manusia pada umumnya dan waria seperti dia juga memiliki taraf kehidupan yang lebih baik dengan orang pada umumnya. Disini pendirian seseorang sangatlah penting karena melakukan pekerjaan dengan keadaan fisiknya seperti waria sangatlah susah, pasti ada seseorang yang mengatakan dan mengejek dalam masyarakat sekitarnya.

Menurut Wandy (2008:1) hanya $53,2 \%$ waktu yang benar-benar produktif yang digunakan untuk bekerja secara langsung dan sisanya 39,9\% digunakan untuk kegiatan penunjang. Dalam pernyataan Wandy pekerjaan yang dilakukan belum tentu mencapai 100\% dalam setiap hari bekerja dan memiliki setengahnya untuk kegiatan penunjang. Dalam pekerjaan mempunyai porsi pekerjaan yang memiliki pekerjaan berat dan ringan, pekerjaan ringan memiliki jam bekerja yang lama dan bisa seharian dan pekerjaan berat memiliki waktu kerja yang terlatif normal. Dalam pekerjaan upahpun menjadi pertimbangan yang sangat dipikirkan dengan matang oleh pengusaha-pengusaha pemiliki modal.

Di Indonesia upah menjadi hal yang penting bagi pekerja, dengan upah pekerja menerima uang dengan apa yang dilakukan selama sehari ataupun minggu. Upah memiliki waktu penerimaan, penerimaan yang relatif normal satu bulan untuk menerima upah bagi pekerja.Dalam novel tersebut Tabita tidak dibayar oleh mami Nancy, karena upah yang diberikan oleh Tabita yaitu disediakan tempat tinggal dan dianggap Tabita sebagai anaknya. Dengan Tabita diangkat menjadi anak mami Nancy, mami Nancy sangat tidak keberatan dan menjadi mami Nancy meringakan pekerjaan. Perlu diketahui mami Nancy adalah seorang waria yang kaya, dia waria yang memiliki keterampilan menjahit yang sangat bagus.Mami Nancy adalah waria yang mempunyai pendidikan jenjang sarjana.Dulu mami Nancy hanya sekolah SMA dengan keterbatasan biaya.Sampai dia menjadi waria dan merintis usaha 
mami Nancy memiliki uang sendiri dan melanjutkan pendidikannya disebuah kampus swasta. Dengan kerajinannya mami Nancy untuk menyuseskan usahanya mami Nancy sangat berjuang demi cita-citanya. Hal yang bisa dicontoh oleh mami Nancy adalah ketekunannya dalam menjalankan usahanya dengan merintis hingga menjadi sukses. Mami Nancy tidak mempermasalahkan omongan diluar sehingga dia teguh dengan pendirianya. Hal yang dicontoh oleh Tabita dengan mami Nancy adalah ketekunannya dalam menjalankan usaha, tidak peduli terhadap orang lain dan menjadikan susah payah mami Nancy membuahkan hasil hingga usaha yang dimiliki sekarang yaitu butik menjadi berkembang pesat dan mempunyai cabang dimana-mana.

Perlu diketahui ketika dulu mami Nancy sebelum menjadi kaya dengan usaha butik yang besar, mami Nancy membuka usaha membuat anyaman dari bambu dan mengandalkan keterampilan waktu SMA mami Nancy dengan jurusan tata boga. Dalam kutipan di atas menunjukan keseimbangan kerja dengan waktu dan upah, sebelum bertemu mami Nancy, Tabita bekerja diwarung kopi dengan upah yang cukup untuk dirinya sendiri dan makan setiap hari. Setelah di warung kopi Tabita susah mendapatkan pekerjaan karena tidak ada yang percaya dengan kemampuan yang dimiliki. Sekali Tabita melamar pekerjaan tapi mendapatkan sindiran terhadap penampilannya. Tujuan Tabita melamar pekerjaan karena Tabita ingin mendapatkan kedudukan yang sama dimata masyarakat sekitar dan sahabatnya dan meningkatkan taraf mutu kehidupan Tabita berikutnya. Jadi, kesimpulan yang dilakukan Tabita dengan dia mencari pekerjaan adalah mencari nafkah dengan melanjutkan kehidupan selanjutnya. Untuk membentuk penasaran pembaca Tokoh Tabita diceritakan sebagai seseorang yang menjadi pengangguran yang sangat susah mencari pekerjaan pada mestinya seseorang normal. Untuk memperejelas dengan penelitian ini diterangkan secara jelas.

\section{Tidak diterima dengan baik oleh masyarakat}

Kematian waria akibat kecelakaan yang mengakibatkan waria tersebut meninggal dan pihak keluarga bingung untuk memakamkan jenazah karena tidak diterima dipemakaman umum dan ingin dimakamkan dengan cara kristen pihak keluarga tidak menemukan pendeta yang mau merawat jenazah waria tersebut. Stereotip tidak diterima dengan baik oleh masyarakat tergambarkan sebagai berikut.

Kami bahkan sampai berdebat bahwa kamu harus dimakamkan dengan cara apa. $Y a$, awalnya aku dan mami sama, kami berpatokan pada KTP-mu, tapi kurasa Ahmad benar. Aku harus menjadi kamu.Pikiran Tania mengembara kembali.Ya, Tania menyadari, di panti mereka tak pernah membicarakan masalah agama.Bukan berarti tak beragama, atau tak menganggapnya sebagai hal yang penting.Mereka beragama dan mereka menjalankan tuntutan itu dengan sebaik-baiknya.Namun bagi mami Nancy, dan ini jualan yang ditularkan ke anak-anakny, bahwa agama adalah properti pribadi.Agama seperti pilihan baju yang mereka kenakan, bukan menunjukan kebaikan hati kepada seseorang. Maka asalkan kau baik dan sopan, apapun pemakaianmu, kau 
akan diterima dengan tangan terbuka dan senang hati di srikandi utama. (Julionatan, 2019:97)

Terlihat dalam kutipan pada Novel bahwa waria tidak diterima dengan baik oleh masyarakat. Terdapat permasalahan terhadap lingkungan di sekitar waria, dengan adanya stereotip waria yang berbagai macam anggapan oleh masyarakat yang cenderung negatif, maka mayarakat membatasi pergaulan dan menciptakan sekat-sekat sosial terhadap waria dengan tujuan agar tidak ikut terjerumus ke dalam kehidupan waria tersebut.

Maaf, ibu, kami tidak menolak, ibu. Tapi kami takut kuwalat. Kami tidak bisa memakamkan Tabita dipemakaman umum, uztad amir mencoba memberikan pemahaman akan apa yang dirasakan warga kepada Nancy dan Tania. Nancy terpukul, tapi dia paham benar konsekuensinya menjadi waria, dan konsekuensinya Tabita tidak untuk memeluk agama. Hingga ia tak banyak berdebat. Ia berlalu dari hadapan warga. Sambil terisak, ia memerika teleponnya. Menelpon seseorang.Ia menelpon Dina. Padanya Nancy bercerita tentang permasalahan yang tengah ia hadapai. (Julionatan, 2019, hlm. 124)

Dalam kutipan novel tersebut menjelaskan Tabita yang tidak diterima oleh masyarakat seketika dia sedang meninggal dan waktu yang genting untuk prosesi pemakamanya. Karena Tabita tidak pernah ke masjid tapi sering ke gereja tapi tidak terdaftar sebagai anggota jemaat mingguan digereja.Serentak warga disekitar tempat tinggal Tabita menjadi bingung dengan identitas Tabita tersebut dengan perbuatan yang dilakukan semasa dia hidup. Demikian mami Nancy bingung dengan penjelasan seorang warga yang menjadi bantuan untuk menguburkan jenazah Tabita.Dengan semasa hidupnya Tabita seperti yang sudah diterangkan. Mami Nancy menjadi bingung dengan cara apa dia menguburkan jenazah mami Nancy. Dengan cara islam dimakamkan dipemakaman umum Tabita tidak pernah ke masjid, dengan cara Kristen Tabita tidak menjadi anggota jemaat walaupun setiap minggu Tabita rutin menjadi jemaat digereja sehingga pendeta yang dimitai tolong untuk memakamkan Tabita tidak bisa menyetujui tawaran Ahmad Dengan demikian ada seseorang kerabat Tania dari desa yang beragama Kristen, yang sudah berpengalaman menjadi pendeta saat memakamkan jenazah saat pendeta mempunyai halangan.

Setelah Tania berbincang-bincang lewat telepon dan menjelaskan kejadian yang terjadi kepada sahabatnya, seorang pemuda yang dimintai tolong kepada Tania bernama Joni, Joni menyetujui permintaan Tania dan Joni segera mengemas barang bawaan dan langsung menuju terminal.Dengan keputusan Joni, Tania sangat senang.Tania menghampiri mami Nancy dan menjelaskan kejadian tersebut dan mami Nancy kelihatan senang sekali.Setelah sehari jenazah Tabita diputuskan untuk dibawa pulang dulu, tidak lama paginya seseorang pendeta muda yang bernama Joni tersebut dating.Setelah jenazah diurus dengan kepercayaan Kristen, jenazah lalu dimakamkan ditempat pemakaman Kristen terdekat. Menurut Koentjaraningrat (2009, hlm. 115-118) kontinuitas merupakan kesatuan masyarakat yang memiliki ke empat ciri yaitu: 1) interaksi antara warga-warganya, 2) adat istiadat, 3)kontinuitas waktu, 4) rasa identitas kuat yang meningkat semua warga. Dalam kutipan pernyataan diatas bisa dilihat bahwa masyarakat mempunyai 
nilai penting yang harus ditanamkan bagi kehidupan bermasyarakat. Sebagai makhluk sosial tidak melepaskan peran lain kepada orang disekitarnya. Dari keempat landasan teori tersebut merupakan teori yang dilakukan untuk menjalankan kehidupan bermasyarakat dengan baik. Untuk memahai dengan jelas seseorang harus sering berinteraksi terhadap sesema.

Dalam kutipan bisa dijelaskan sebagai berikut. 1) interaksi antar wargawarganya yang dimaksud sebagai pemimpin lebih baik mempunyai kedekatan emosional terhadap warganya. Dikarenakan warga memerlukan komunikasi yang berhubungan dengan kendala-kendala dalam menjalani hidup setiap hari, dalam berinteraksi antar warga pemimpin juga mempunyai dan menambah kedekatan terhadap masyarakat. 2) adat istiadat yang dimaksud yaitu sebagai sekelompok masyarakat tidak akan pernah lepas dengan adat istiadat yang dimiliki sejak dulu, terutama adat istiadat yang ditinggalkan nenek moyang. Dalam adat istiadat dan masyarakat harus perlu dilestarikan karena dengan adanya adat istiadat menjadikan kehidupan antar masyarakat menjadi rekat dan semakin akrab satu sama lain. 3) kontinuitas waktu yang dimaksud yaitu dalam masyarakat harus mempertimbangkan kontiunitas waktu. Kontinuitas waktu yaitu keseimbangan atu keselarasan. Untuk menjadikan masyarakat yang damai harus menyelaraskan tujuan yang tidak sama dalam masyarakat. 4) rasa identitas yang kuat yaitu identitas dalam masyarakat harus memiliki kelengkapan yang kuat. Dalam beragama bermasyarakat harus memiliki sehingga bisa membedakan suatu keyakinan yang ada. Untuk identitas tersebut berkaitan dengan Tabita yang tidak memiliki identitas dan dipermasalahkan didalam novel.
Identitas sangatlah penting karena untuk mengetahui siapa dan apa keyakinan yang dianutnya untuk memperlihatkan keyakinan yang dianutnya. Jadi, Tabita tidak diterima dimasyarakat karena tidak memiliki identitas keyakinan dalam masyarakat. Karena identitas sangat penting dan termasuk kesatuan masyarakat dalam kutipan di atas dan menjadikan Tabita tidak diterima di masyarakat karena tidak memiliki identitas dengan jelas. Menurut (Durkheim, 2011, hlm. 11) masyarakat merupakan suatu kenyataan yang objektif secara mandiri, bebas dari individuindividu yang merupakan anggotaanggotanya. Dalam kutipan tersebut yaitu masyarakat yang objektif secara mandiri yang merupakan bebas dari individu yang bersifat menyeluruh.Jadi, masyarakat menurut kutipan yaitu suatu satu golongan yang bersifat kemasyarakatan.Berkaitan dengan novel tersebut Tabita tidak bisa berinteraksi terhadap masyarakat ditempat dia tinggal karena tidak memiliki suatu keluarga yang utuh sehingga dia memilih untuk mendiamkan diri karena rasa malu akibat fisik dan tidak mempunyai keluarga dengan utuh.Jadi, dalam permasalahan Tabita tidak diterima dengan baik oleh masyarakat yaitu tidak mempunyai keluarga secara utuh dan dengan kondisi fisik mengakibatkan rasa malu dalam melakukan interkasi terhadap masyarakat sekitar tempat tinggal Tabita.

\section{KESIMPULAN}

Dalam novel Rumah Ilalang karya Stebby Julionatan menceritakan tentang Stereotip kehidupan waria dikalangan masyarakat. Direpresentasikan dalam tiga aspek, yaitu (1) tidak beragama, (2) tidak memiliki pekerjaan yang tetap, (3) tidak diterima dengan baik oleh masyarakat. Kehidupan waria sangatlah menggambarkan kehidupan pada zaman sekarang yang merupakan sebuah keinginan untuk menjadi sesuatu yang 
berbeda. Didalam novel tersebut terjadi permasalahan penggambaran waria yang cenderung negatif, karena waria tidak memiliki identitas diri dengan jelas. Hal tersebut karena orientasi masyarakat yang memilik pandangan yang kurang baik terhadap waria. Stereotip yang terdapat dalam penelitian ini yaitu waria tidak memiliki kepercayaa, tidak memiliki identitas, dalam pekerjaan dianggap tidak mampu bekerja dan dalam masyarakat mempunyai batas-batas kehidupan di lingkungan sekitar.

\section{DAFTAR PUSTAKA}

Allport, G. W. (1950). The Individual and his Religion: a Psychological Interpretation. New York: The Macmillan Company.

Andalas, E. F. (2017). Eskapisme Realitas Dalam Dualisme Dunia Alice Telaah Psikologi-sastra Film Alice in Wonderland (2010). KEMBARA: Jurnal Keilmuan Bahasa, Sastra, Dan Pengajarannya, 3(2), 185-195.

Andalas, E. F., \& Prihatini, A. (2018). Representasi Perempuan dalam Tulisan dan Gambar Bak Truk: Analisis Wacana Kritis Multimodal Terhadap Bahasa Seksis. Satwika, 2(1), 1-19. Retrieved from http://ejournal.umm.ac.id/index.php/J ICC/article/view/7018

Arivia, G. (2002). Pembongkaran Wacana Seksis Filsafat Menuju Filsafat Berperspektif Feminis. Universitas Indonesia.

Artawan, I. G. (2015). Mimikri dan Stereotipe Kolonial Terhadap Budak dalam Novel-Novel Balai Pustaka. Jurnal Ilmu Sosial Dan Humaniora, 4(1), 577-584. https://doi.org/http://dx.doi.org/10.23 887/jish-undiksha.v4i1.4926
As'ad, S. U. M. (2002). Psikologi industri: Seri Ilmu Sumber Daya Manusia. Yogyakarta: Liberty.

Baron, R. A., Branscombe, N. R., \& Byrne, D. (2008). Social Psychology. Boston: Pearson.

Clark, H. W. (1958). A Introdution to The Psychology of Religion: an introdution to Religion Experience and Behaviour. New York: The Macmillan Company.

Damono, S. D. (1978). Sosiologi Sastra. Jakarta: Pusat Pembinaan dan Pengembangan Bahasa, Departemen Pendidikan dan Kebudayaan.

Durkheim, E. (2011). The Elementary Forms of the Religious Life: Sejarah Bentuk-Bentuk Agama yang Paling Dasar. Yogyakarta: IRCiSoD.

Earles, J. (2016). Reading Gender: a Feminist, Queer Approach to Children's Literature and Children's Discursive Agency. Gender and Education, 29(3), 369-388. https://doi.org/https://doi.org/10.1080 /09540253.2016.1156062

Fibiani, M., \& Andalas, E. F. (2020). The "I" Character Perspective on the Life of Balinese Ubud Society: Symbolic Meaning in Jangan Sisakan Nasi dalam Piring. Jurnal Kata: Penelitian Tentang Ilmu Bahasa Dan Sastra, 4(1), 44-58.

Franzoi, S. L. (2008). Social Psychology. New York: McGraw-Hill Company.

Gea, A. A. (2006). Relasi Dengan Tuhan. Jakarta: Elex Media Komputindo.

Iman, N., \& Andalas, E. F. (2019). Representasi Kehidupan Religius Masyarakat Islam Kejawen Di Yogyakarta Pada Tahun 1868 M- 
1912 M dalam Novel Dahlan: Sebuah Novel Karya Haidar Musyafa. Pena Literasi, 2(1), 189200.

Julionatan, S. (2019). Rumah Ilalang. Yogyakarta: Basa Basi.

Kartikasari, R., Anoegrajekti, N., Maslikatin, T., Salah, A., Herliany, D. R., Sosial, R., ... Nugroho, M. B. (2014). Realitas Sosial dan Representasi Fiksimini dalam Tinjauan Sosiologi Sastra. PUBLIKA Budaya, 2(1), 50-57. https://doi.org/10.1017/CBO9781107 415324.004

Koentjaraningrat. (2009). Pengantar Ilmu Antropologi. Jakarta: Rineka Cipta.

Nurgiyantoro, B. (2010). Teori Pengkajian Fiksi. Yogyakarta: Gadjah Mada University Press.
Paynter, K. C. (2011). Gender Stereotypes and Representation of Female Characters in Children's Picture Books. Dr Diss Proj [Internet]. Retrieved from http://digitalcommons.liberty.edu/doc toral $/ 464$

Stangor, C. (2011). Research Method for Behavioral Science. . Wadsworth: Cengage Learning.

Sugiarti, Andalas, E. F., \& Setiawan, A. (2020). Desain Penelitian Kualitatif Sastra. Malang: UMM Press.

Sugiarti, S., \& Andalas, E. F. (2018). Pespektif Etik dalam Penelitian Sastra. Malang: UMM Press.

Wulff, D. M. (1991). Psychology of Religion. Illinois: Foreman and Company. 